\title{
SISTEM ADMINISTRASI PELAYANAN PEMERINTAH DESABERBASIS WEBSITE STUDI KASUS KANTOR BALAI DESAKENDALKEMLAGI KECAMATAN KARANGGENENG KABUPATEN LAMONGAN
}

\author{
Putra Samudra $^{1)}$, Siti Mujilahwati' ${ }^{2)}$, M.Ghofar Rohman ${ }^{3)}$ \\ 1)Program Studi Teknik Sipil,Teknik Elektro,Teknik Informatika Universitas Islam Lamongan \\ 2) Dosen Fakultas Teknik Prodi Teknik.... Universitas Islam Lamongan \\ 3) Dosen Fakultas Teknik Prodi Teknik.... Universitas Islam Lamongan
}

Email : Samoedra99@gmail.com ${ }^{1)}$, Modjee@gmail.com ${ }^{2)}$ M.Ghofarohman@Unisla.ac.id ${ }^{3)}$

\begin{abstract}
ABSTRAKS
Dalam pemerintahan desa ditemukan beberapa permasalahan, mulai dari pelayanan surat keluar yang kurang rapi, pembuatan laporan registrasi kependudukan hingga kesulitan dalam pembuatan rencana anggaran pendapatan dan belanja desa. Untuk menyelesaikan permasalahan yang ada, maka dibuat sebuah Sistem Administrasi Pelayanan Pemerintah Desa (SAPPDESA) Berbasis Website menggunakan metode waterfall. Metode waterfall ini merupakan metode yang digunakan dalam sebuah perancangan perangkat lunak. Website adalah suatu halaman web yang saling berhubungan dan berisikan kumpulan informasi yang disediakan secara perorangan, kelompok, atau organisasi. Dalam aplikasi ini disediakan beberapa jenis surat keterangan maupun formulir kependudukan yang disediakan oleh pemerintah desa setempat yang dapat diajukan oleh masyarakat tanpa harus datang ke kantor balai desa. Tujuan utama dari pembuatan sistem ini adalah untuk mendukung program pemerintah dalam meningkatkan pelayanan publik kepada masyarakat. Ada beberapa fitur utama yang ada dalam aplikasi, yaitu memiliki nomor surat yang didesain otomatis, penomoran tanggal, serta memiliki seluruh surat yang disediakan di Kantor Balai Desa.
\end{abstract}

Kata Kunci : Sistem Administrasi, Website Desa, Sappdesa

\begin{abstract}
In the Government of the village found some problems, ranging from the outgoing mail service which is less tidy, making residency registration to report difficulty in making the plan of budget revenue and expenditure of the village. To resolve the problems that exist, it is created a system of Administrative Service of the Government of the village (SAPPDESA) based on websites using the method waterfall. the waterfall method is a the method used in a design software. The website is a web page that contains a collection of interconnected and information is provided for individual, group, or organization. In this application provided some type of form or certificate of residence provided by the local village government that may be filed by the public without having to come to the Office of the village hall. The main objective of the creation of this system is to support the Government in improving public services to the community. There are several key features that exist in the application, that has a number of mail-designed automatic numbering, date, as well as having the entire letter is provided at the Office of the village Hall.
\end{abstract}

Keyword : Administration System, Village Website, Sappdesa

\section{PENDAHULUAN}

Dalam bab ini akan memuat mengenai Latar Belakang, dan Tujuan serta Kegunaan Hasil Penelitian. Dimana muatan-muatan tersebut dijelaskan sebagai berikut:

Pada dasarnya administrasi kependudukan merupakan sub sistem dari adminstrasi negara, yang memiliki peran penting dalam pemerintahan dan penyelenggaraan administrasi kependudukan. Dalam proses administrasi kependudukan sering menuai masalah, karena sistem administrasi pemerintahan desa yang berjalan saat ini masih menggunakan sistem manual. Dengan pemanfaatan teknologi informasi saat ini dapat digunakan untuk membangun sebuah sistem administrasi kependudukan yang akurat, terpercaya dan up to date. Maka dalam penelitian ini akan dirancang sebuah sistem administrasi desa 
berbasis website dengan menggunakan metode waterfall. Karena website dirasa paling cepat, efektif serta efisien untuk mendukung program pemerintah desa dalam rangka meningkatkan kualitas pelayanan publik kepada masyarakat.

Tujuan yang ada pada penelitian ini adalah untuk membuat sebuah sistem administrasi pemerintah desa berbasis website dengan menggunakan metode waterfall untuk menyelesaikan permasalahan yang ada dalam penelitian ini.

Manfaat dari pembuatan aplikasi ini akan dirasakan oleh warga dan pemerintah desa setempat. Masyarakat desa akan dimudahkan untuk mengajukan surat keterangan maupun formulir kependudukan serta petugas registrasi yang ada di kantor balai desa akan mendapatkan informasi laporan administrasi secara cepat, efektif dan efisien sesuai dengan data yang telah diajukan oleh warga.

\section{Tinjauan Pustaka/Referensi}

Dalam bab ini terdapat beberapa teori yang mendukung penelitian ini, diantaranya adalah :

Menurut Agus (2015, h.10), Administrasi desa adalah keseluruhan proses kegiatan pencatatan data dan informasi mengenai penyelenggaraan pemerintahan desa pada buku administrasi desa. Administrasi desa ditetapkan dengan Keputusan Menteri Dalam Negeri akan tetapi teknis pelaksanaan dan pembinaan operasionalnya ditetapkan dengan Keputusan Bupati berdasarkan UU No. 32 Tahun 2004 tentang Pemerintahan Daerah.

Menurut Agus (2015, h.22), Anggaran Pendapatan dan Belanja Desa (APBDesa) merupakan rencana keuangan tahunan pemerintahan desa dan memerlukan Peraturan Bupati/Walikota untuk mengatur mengenai pengelolaan keuangan desa. Pengelolaan keuangan desa adalah keseluruhan kegiatan yang meliputi perencanaan, pelaksanaan, penatausahaan, pelaporan dan pertanggungjawaban keuangan desa.

Menurut Rosa dan M. Salahudin. (2013, h. 1), Rekayasa Perangkat Lunak adalah sebuah profesi yang dilakukan oleh seorang perekayasa perangkat lunak yang berkaitan dengan pembuatan dan pemeliharaan aplikasi perangkat lunak dengan menerapkan teknologi dan praktik dari ilmu komputer, manajemen proyek, dan bidang-bidang lainnya. Dalam penelitian ini akan menggunakan metode waterfall yang ada dalam rekayasa perangkat lunak untuk menyelesaikan permasalahan yang ada. Gambar 1 merupakan sebuah model air terjun akan memacu tim pengembang untuk merinci apa yang seharusnya perangkat lunak lakukan.

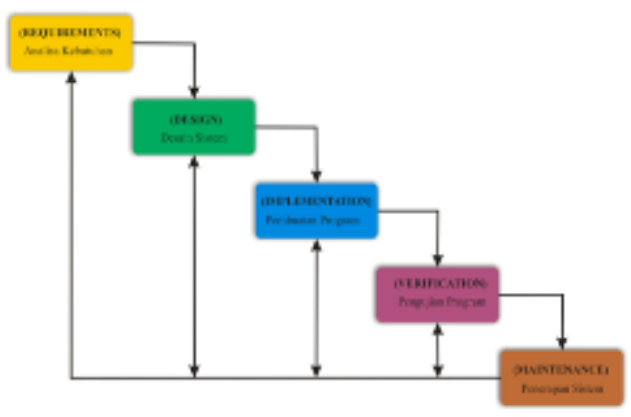

Gambar 1 Model Waterfall

Menurut didik (2013, h.1), merupakan sebuah software yang akan dijadikan sebagai perangkat lunak acuan dalam pembuatan aplikasi administrasi desa ini. Dalam penelitian ini akan dibuat sebuah aplikasi administrasi desa berbasis website. Dalam penelitian ini akan dikembangkan mulai dari perbaikan sistem yang berjalan, tampilan aplikasi, tingkat keamanan aplikasi, serta peningkatan dalam kemudahan penggunaannya. Dalam penelitian ini nomor surat akan dibuat secara otomatis sesuasi dengan urutan terakhir, sehingga penggua tidak memasukkan nomor secara manual.

\section{PEMBAHASAN}

Dalam bab ini berisi mengenai beberapa pembahasan yang ada dalam penelitian ini, diantaranya adalah :

Dalam tahapan analisa sistem yang sedang berjalan, ditemukan bahwa sistem registrasi kependudukan yang berjalan di Kantor Balai Desa masih kurang rapi atau tidak teratur. Terbukti dari banyaknya pencatatan arsip penduduk yang tidak dibedakan antara kategori yang satu dengan yang lainnya. Seluruh pelayanan akan ditulis dalam sebuah buku dan tidak dibedakan sesuai dengan kategori masingmasing saat dilakukan pencarian data.

Pembuatan aplikasi ini sangat dibutuhkan dalam sistem administrasi yang berjalan di Kantor Balai Desa. Dalam sebuah sistem adminitrasi dibutuhkan kecepatan serta 
ketepatan pengolahan data sampai laporan, yang bertujuan untuk dapat meminimalisir kesalahan yang dilakukan oleh petugas registrasi yang bertugas di Kantor Balai Desa. Sehingga ikut mendukung program pemerintah pusat untuk meningkatkan pelayanan publik kepada masyarakat.

Untuk menyelesaikan permasalahan adminitrasi yang ada pada kantor balai desa kendalkemlagi kecematan karanggeneng, maka akan dibuat blok diagram, berupa data flow diagram yang digunakan untuk menggambarkan suatu sistem yang telah ada atau sistem baru yang akan dikembangkan secara logika sesuai dengan kebutuhan.

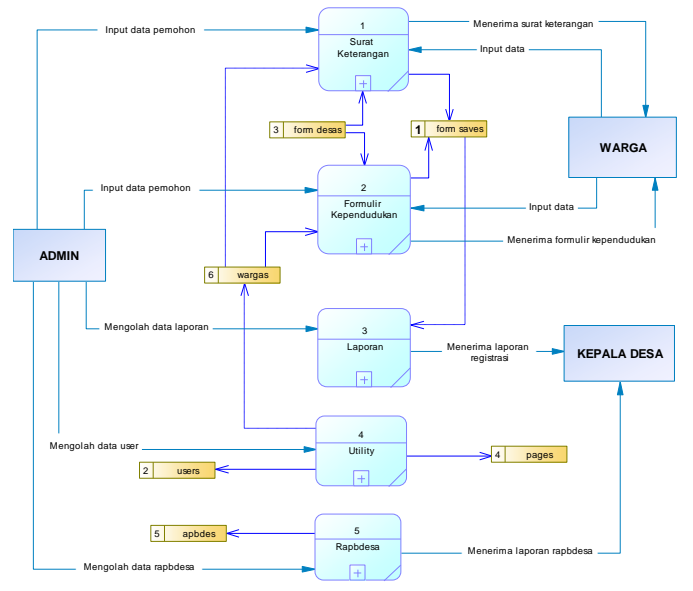

Gambar 2 Data Flow Diagram

Dalam desain diatas dijelaskan mengenai cara kerja dari sistem yang akan dibangun, terdapat sebanyak 5 proses yang akan dijalankan yaitu surat keterangan yang memiliki sebanyak 18 macam surat keterangan yang dapat diajukan oleh masyarakat setempat; Dalam proses formulir kependudukan memiliki sebanyak 8 macam formulir kependudukan, salah satunya adalah form permohonan kartu tanda penduduk.

Dalam proses laporan yang dijalankan oleh admin akan menghasilkan output berupa laporan registrasi kependudukan yang nantinya diberikan kepada kepala desa setempat; Dalam proses utility dijalankan oleh admin untuk memasukkan data warga sesuai dengan data yang terdaftar pada kantor balai desa, yang bertujuan untuk mempercepat proses administrasi yang berjalan; dan

Proses rapbdesa merupakan rancangan anggaran pendapatan dan belanja desa yang disusun setiap tahun. Rapbdesa ini digunakan untuk membantu petugas administrasi selaku perangkat desa setempat dalam merancang anggaran pendapatan dan belanja desa. Dalam perancangan sistem ini juga dibuat Information Oriented Flowchart (IOFC) yang akan menjelaskan alur kerja sistem secara keseluruhan.

Tabel 1 Desain IOFC

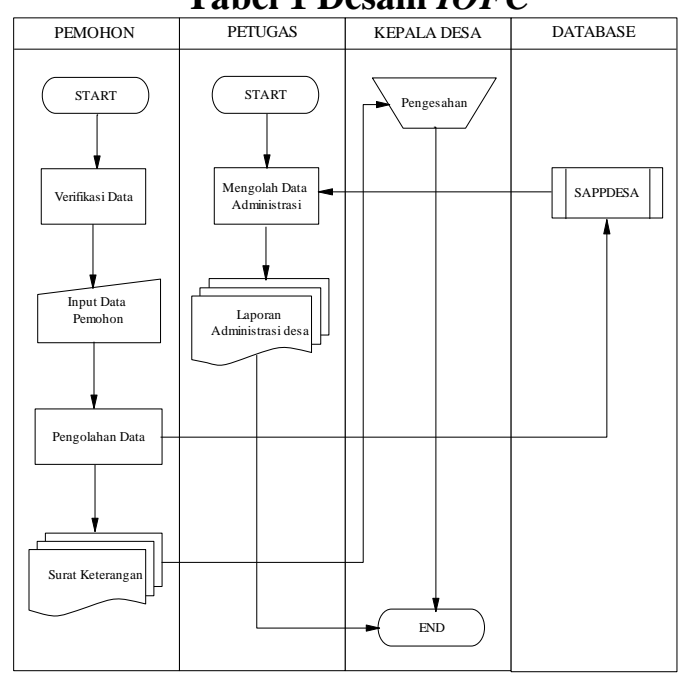

Dalam alur yang dibuat, warga dapat melakukan pengajuan surat kependudukan langsung melalui website tanpa harus mengantri dikantor balai desa. Aplikasi akan melakukan verifikasi data terhadap nomor induk kependudukan (nik) yang dimasukkan oleh masyarakat, apabila nik yang dimasukkan, terdaftar dalam data kependudukan yang ada di kantor balai desa setempat maka masyarakat dapat mengajukan surat sesuai dengan yang dibutuhkan.

Pada penelitian ini menggunakan metode pengujian black box testing yang berfokus pada persyaratan fungsionalitas perangkat lunak. Penanganan kesalahan (error handling), dan white box testing adalah pengujian yang didasarkan pada pengecekan terhadap detail perancangan menggunakan struktur kontrol dari desain program secara procedural untuk membagi pengujian kedalam beberapa kasus pengujian.

Setelah dilakukan pengujian pada sistem administrasi pelayanan pemerintah desa berbasis website menggunakan kedua metode ini, maka peneliti mendapatkan hasil bahwa program yang dibuat sudah sesuai dengan 
perancangan sistem yang diinginkan, untuk menyelesaikan permasalahan yang dihadapi dalam penelitian ini.

Keunggulan dari sistem baru yang dibuat ini adalah terdapat sebanyak 26 jenis surat sesuai yang terdapat dikantor balai desa. Masyarakat dapat langsung memilih dan mengajukan beberapa jenis surat yang ada yang dapat dilihat pada gambar 3

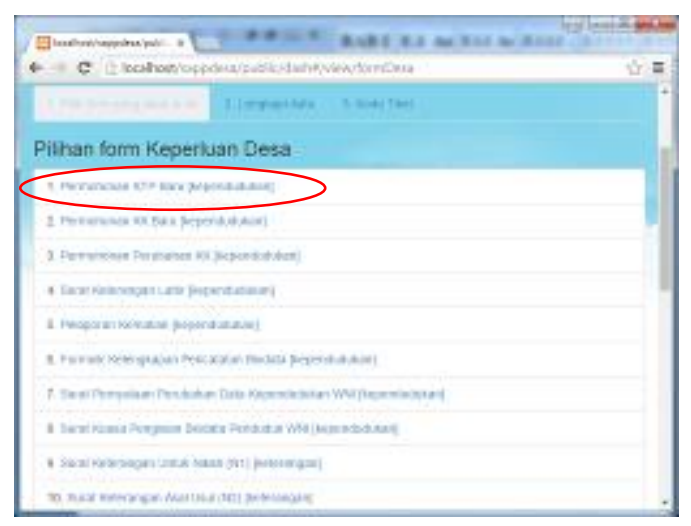

Gambar 3 Daftar Surat Permohonan

Salah satu contoh surat yang ada dalam daftar adalah permohonan kartu tanda penduduk baru sesuai dengan Permendagri No. 19 Tahun 2010 mengenai formulir kependudukan. Setelah memilih surat permohonan yang ingin diajukan, maka akan muncul form untuk memasukkan nik yang ada pada gambar 4

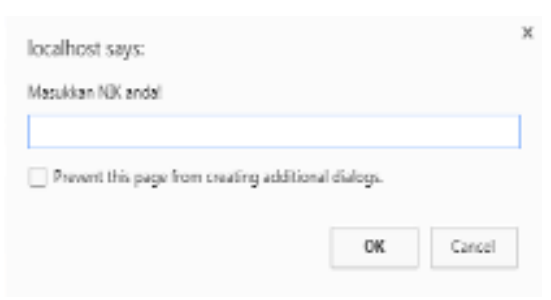

\section{Gambar 4 Input NIK}

Apabila nomor induk kependudukan yang dimasukkan terdaftar pada aplikasi, maka akan muncul form pengisian permohonan kartu tanda penduduk. Form akan terisi secara otomatis sesuai dengan yang terdapat pada data yang terdaftar dikantor balai desa, sehingga pemohon tinggal melengkapi beberapa kategori yang belum terisi.

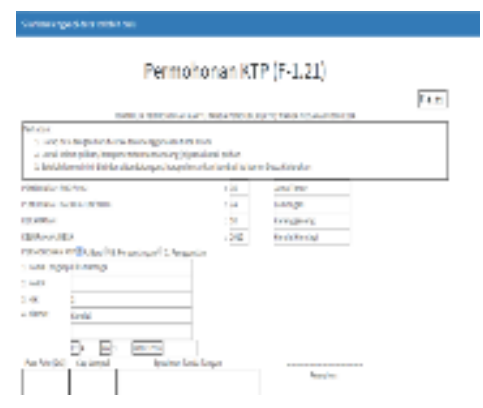

\section{Gambar 5 Form Pengisian}

Setelah mengisi data pada form yang disediakan, maka pemohon dapat mengajukan surat tersebut. Pemohon akan mendapatkan sebuah nomor tiket yang dibawa ke kantor balai desa untuk mengambil surat keterangan yang telah diajukan sebelumnya.

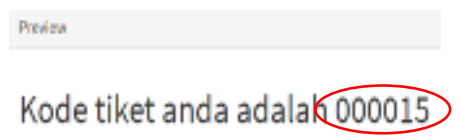

\section{Gambar 6 Kode Tiket}

Sistem pengajuan dengan menggunakan nomor tiket diatas berlaku untuk semua surat yang ada dalam daftar. Admin akan melakukan pencetakkan surat yang telah diajukan sesuai dengan nomor tiket yang ada, admin akan melakukan pengecekkan pada registrasi form warga pada gambar 7

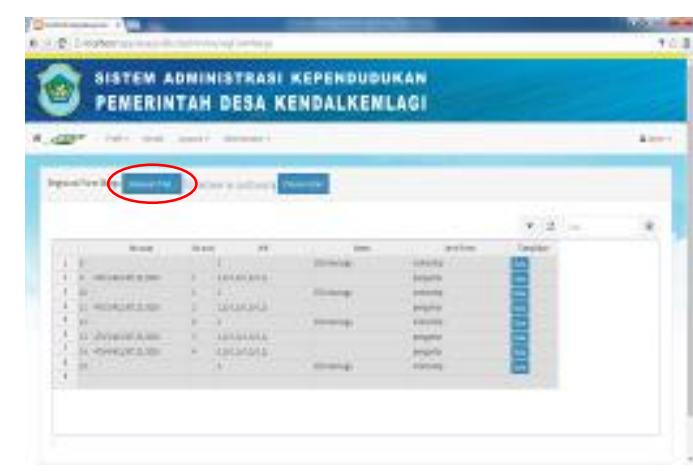

Gambar 7 Registrasi Form Warga

Admin akan melakukan pengecekkan tiket yang diberikan oleh pemohon untuk mencetak surat yang telah diajukan sebelumnya. 


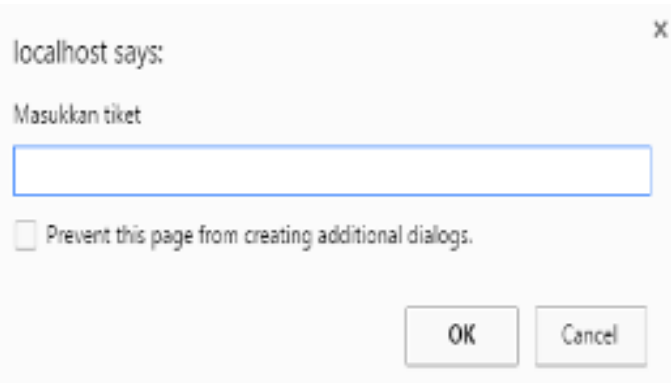

\section{Gambar 8 Input Tiket}

Apabila nomor tiket yang dimasukkan terdapat pada registrasi kependudukan, maka akan muncul surat permohonan tersebut dan siap untuk dicetak.

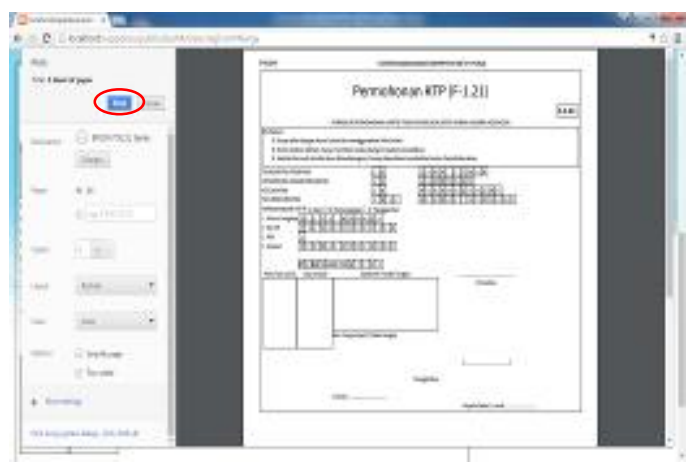

\section{Gambar 9 Tampilan Cetak Surat}

Proses pengecekkan serta pencetakkan ini berlaku untuk semua pengajuan yang telah dilakukan oleh masyarakat. Selain menjalankan sistem diatas, admin juga melakukan proses pengolahan laporan registrasi kependudukan yang akan diberikan kepada kepala desa. Gambar 10 merupakan tampilan laporan registrasi kependudukan

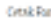

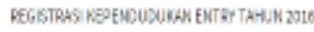

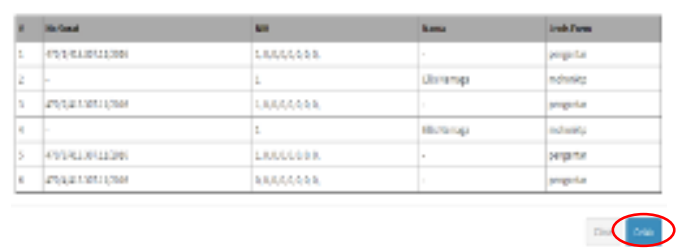

\section{Gambar 10 Registrasi Kependudukan}

Dibanding aplikasi desa pelayanan prima (ADPP) yang dijadikan sebagai perangkat lunak acuan, sistem yang dibuat ini memiliki beberapa kelebihan, yaitu memiliki sistem yang dapat digunakan untuk merancangan anggaran pendapatan dan belanja desa (RAPBDESA) yang saat ini sangat dibutuhkan oleh pemerintah desa. Dalam menu input APB desa, admin dapat memasukkan anggaran yang ada dalam perancangan APB desa yang akan diproses oleh sistem aplikasi.

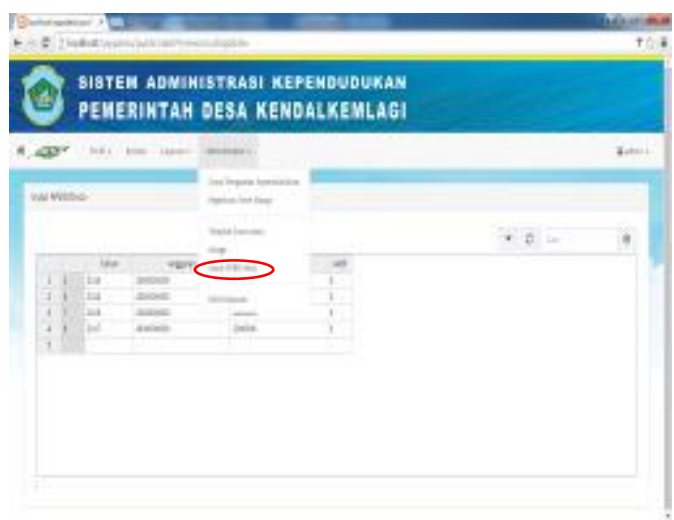

Gambar 11 Input APB Desa

Setelah admin berhasil memasukkan data APB desa yang telah dimasukkan sebelumnya, maka masyarakat dapat mengecek laporan pada menu layanan APBD Desa, yang dapat diakses oleh seluruh user.

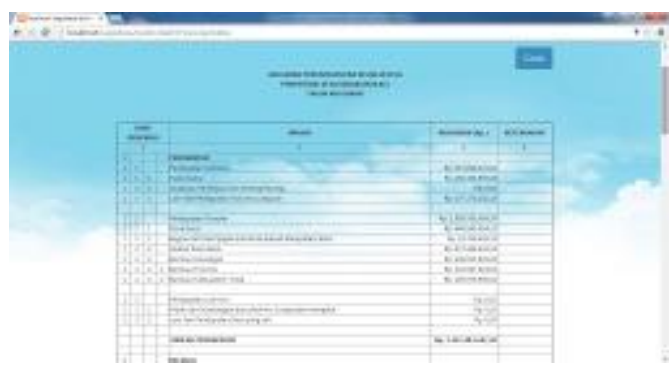

\section{Gambar 12 APB Desa}

Gambar diatas merupakan rancangan APB desa yang telah disusun oleh petugas balai desa selaku admin, seluruh pengguna dapat mencetak laporan APB desa diatas, sehingga masyarakat dapat ikut berperan aktif dalam proses pemerintahan desa yang sedang berjalan. Gambar 13 merupakan tampilan cetak dari APB desa. 


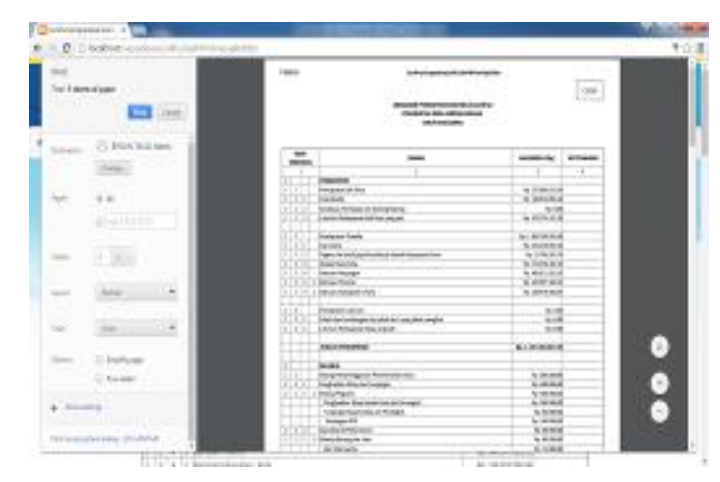

Gambar 13 Cetak APB Desa

\section{KESIMPULAN}

Setelah menyelesaikan penelitian ini, maka dapat ditarik beberapa kesimpulan diantaranya adalah :

1. Aplikasi ini dirancang dan dibuat dengan menggunakan metode waterfall;

2. Keuntungan yang didapat oleh pemerintah desa adalah semakin cepat dalam menjalankan sistem administrasi yang berjalan di pemerintah desa; dan

3. Keuntungan yang didapat oleh masyarakat adalah tidak perlu terlalu lama mengantri untuk mendapatkan pelayanan administrasi yang diberikan oleh pemerintah desa.

Adapun saran yang dapat diberikan oleh peneliti untuk mengembangan aplikasi ini adalah:

1. Penambahan form formulir yang lebih banyak;

2. Perbaikan desain interface; dan

3. Membuat koneksi dengan pemerintah pusat untuk mempercepat pengiriman informasi

\section{PUSTAKA}

Agus, Puji. 2015. Pengelolaan Keuangan Desa : Sistem dan Prosedur Pelaksanaan Keuangan Desa. Jakarta https://www.bppk.kemenkeu.go.id

Didik Kurniawan, Welly. 2013. Aplikasi Desa Pelayanan

Prima (ADPP). Tulungagung:https://visiecom.co.id/aplikasidesa, diakses pada 03 November 2015

Dinas Kependudukan dan Pencatatan Sipil Kabupaten Lamongan. 2014. Tugas dan Tanggungjawab Petugas Registrasi. Lamongan : Dinas Kependudukan dan Pencatatan Sipil Kabupaten Lamongan.

Rosa A.S, M. Salahudin. 2013. Rekayasa Perangkat Lunak : Terstruktur dan Berorientasi Objek. Informatika. 